This is an electronic reprint of the original article. This reprint may differ from the original in pagination and typographic detail.

Author(s): Kivijärvi, Marke; Mills, Albert J.; Mills, Jean Helms

Title: $\quad$ Historic constructions of the early multinational : On power, politics and culture in Pan Am narratives

Year: $\quad 2018$

Version:

Please cite the original version:

Kivijärvi, M., Mills, A. J., \& Mills, J. H. (2018). Historic constructions of the early multinational : On power, politics and culture in Pan Am narratives. International Journal of Business and Globalisation, 20(2), 222-250.

https://doi.org/10.1504/IJBG.2018.10010230

All material supplied via JYX is protected by copyright and other intellectual property rights, and duplication or sale of all or part of any of the repository collections is not permitted, except that material may be duplicated by you for your research use or educational purposes in electronic or print form. You must obtain permission for any other use. Electronic or print copies may not be offered, whether for sale or otherwise to anyone who is not an authorised user. 


\title{
Historic constructions of the early multinational: on power, politics and culture in Pan Am narratives
}

\section{Marke Kivijärvi}

Jyväskylä University School of Business and Economics, University of Jyväskylä,

P.O. Box 35,

FI-40014, Jyväskylä, Finland

Email: marke.t.kivijarvi@jyu.fi

*Corresponding author

\author{
Albert J. Mills \\ Sobey School of Business, \\ Saint Mary’s University, \\ Sobey Building, 903 Robie Street, \\ Halifax, Nova Scotia, B3H 3C3, Canada \\ and \\ Business School, \\ University of Eastern Finland, \\ Kuopio, Finland \\ Email: albert.mills@smu.ca
}

\section{Jean Helms Mills}

Sobey School of Business, Saint Mary's University, Sobey Building, 903 Robie Street, Halifax, Nova Scotia, B3H 3C3, Canada

Email: jean.mills@smu.ca

\begin{abstract}
This paper examines how Pan American World Airways (Pan Am) an early incarnation of a multinational enterprise (MNE) - developed its image as an international company. In particular we examine how the company developed and managed potentially conflicting narratives, including the modernising US company and the airline of 'the Americas' (specifically South America); the carrier of US national interests and the politically neutral actor serving to unify cultures; the purveyor of exotic experiences and the pioneer of modernism. Through a focus on organisational narratives we reveal the powerful influence of such story telling (through design and serendipity) on images of the peoples and countries where the MNE operates. In contributing to the narrative turn in business history we argue for a relational approach to narrative analysis.
\end{abstract}

Keywords: business history; corporate archives; narrative; international business; multinational companies; postcolonialism; airlines; relationalism. 
Reference to this paper should be made as follows: Kivijärvi, M., Mills, A.J. and Helms Mills, J. (xxxx) 'Historic constructions of the early multinational: on power, politics and culture in Pan Am narratives', Int. J. Business and Globalisation, Vol. X, No. Y, pp.xxx-Xxx.

Biographical notes: Marke Kivijärvi is a University Teacher of management and leadership at the Jyväskylä University School of Business and Economics. She received her PhD from the University of Eastern Finland - focusing on postcolonial discourse in Finnish business actors' strategy making vis-à-vis the Chinese market. Her research focuses on postcolonialism and gendered discourses of management and leadership.

Albert J. Mills is Professor of management and Director of the $\mathrm{PhD}$ (Management) program at the Sobey School of Business, Saint Mary's University, Canada. His primary interest lays in the study of historiography, the sociology of management knowledge, gender, and management and organisational studies. His 40 books and edited collections include Management and Organization Theory over Time: Development, Dissemination, and Context (Emerald, in press); The Routledge Companion to Management \& Organizational History (2015); ANTi-History: Theorizing the Past, History, Historiography in Management and Organizational Studies (IAP, 2012); and Sex, Strategy and the Stratosphere: The Gendering of Airline Cultures (Palgrave, 2006). He is the Co-Editor of Qualitative Research in Organizations and Management: An International Journal.

Jean Helms Mills is a Professor of Management in the Sobey School of Business, Saint Mary’s University, Canada, Docent at Jyväskylä University School of Business, Finland and has been a Senior Research Fellow at Hanken School of Economics, Helsinki, since 2008. She has presented her work on historiography, critical sensemaking, gender, culture and change at numerous conferences and published in various journals. Currently, she is a Co-Editor of Qualitative Research in Organizations and Management and Associate Editor for Gender, Work and Organization. She is past divisional Co-Chair of the Critical Management Studies Division of The Academy of Management.

This paper is a revised and expanded version of a paper entitled 'Historic constructions of the early multinational: on power, politics and culture in Pan Am' presented at 9th International Conference in Critical Management Studies, Leicester, 8-10 July 2015.

\section{Introduction}

In this article we explore the challenges and resolve of Pan American World Airways (Pan Am) as an early form of the multinational enterprise. Through analysis of some of the major narratives produced by the airline we examine how those narratives serve to make sense of the potential conflicts involved in being primarily headquartered in one (Western) country (see Figure 1) while operating in several others (especially so-called third world countries of 'the South'), and how this in turn is linked to the construction of corporate identity as an international company (or MNE).

Drawing on narrative analysis (Carr, 1991), we draw insights for the development of multinational corporate identity; the role of the multinational enterprise in the production and performance of postcoloniality (i.e., Western productions of images and 
understandings of non-Western subjects (Amoko, 2006); contribute to the case for an historic turn in business studies (Booth and Rowlinson, 2006) and argue for the use of narrative analysis in business history. Furthermore, we take the position that analysing how multinational enterprises constructed their understanding of being an international company in the past, allows us to understand the complexities framing MNE's today. To that end we employ historic analysis as a means to discover how ideas of the multinational enterprise are constructed and change over time.

Figure 1 Pan Am's headquarters in New York (built in 1963) (see online version for colours)

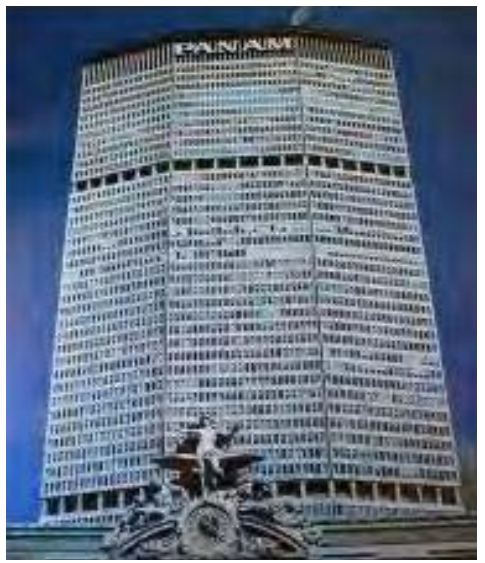

Note: All images and photographs in this article are reproduced with kind permission of the Panam Historical Foundation.

As MNEs have become key drivers of globalisation, they have simultaneously become open to critical questioning including postcolonial commentaries with claims that multinational corporations from Europe and the USA enact imperial practices in Asia, Africa and South America (Banerjee et al., 2009). According to some postcolonial scholars, the power and control of MNEs over their operating environment have "made management into the spearhead of neo-colonialism in the age of decolonization" [Frenkel and Shenhav, (2006), p.871]. Nonetheless, in spite of the growing interest in postcolonial analyses within management and organisation studies, empirical illustrations from organisational settings are scarce (for exceptions see Mir et al., 2008). Boussebaa and Morgan (2014, p.102) propose that examinations of the imperial nature of multinationals may benefit, among others, from "more exploration of the history of MNCs and their function in the imperial enterprise of yesteryear". Accordingly, this paper seeks to deepen our empirically grounded and historical understanding of the issues of power that frame multinational corporations. To achieve this aim we deploy postcolonial theory (Said, 1979; Young, 2001) for analysis of how organisational narratives serve to construct the MNE identity and, in the process, draw on postcolonial understanding of the firm. This, in large part, draws us to Pan Am, an airline whose growth owes much to the building of its routes throughout South America and the Caribbean and with the direct assistance of the US State Department.

Our empirical study consists of a critical examination of narratives produced by Pan Am. We view Pan Am as an early MNE (Wilkins, 1974), which was the primary and 
largest US-based international airline in operation between 1927-1991. By the early 1940s alone the airline was operating flights to every continent across the globe. We focus on the time period 1927 to the early 1940s to trace the relationship between the airline's development and its image(s) as an international company.

In this paper we reveal how the overall narrative of Pan Am rests on glorifying the company's technological advantage and its position as the leading international air carrier. Our detailed analysis of the international aspects of the case illustrates that the various company narratives intertwine culture, politics and power in ways that help to sustain the integrity of the multinational firm in the eyes of different audiences, the local international markets and the home country. That is, in spite of the seeming neutrality of the narratives, a critical deconstruction of the stories reveals the underlying processes that imbue power and control over the international territories in which this US company operates and raise the question of the role that Pan Am played in laying the ground work for the post-World War II neo-colonial actions of the US Government in much of Latin America and beyond (Ellsberg, 2002; Mignolo, 1991; Zinn, 1999).

Through historical analysis, and specifically narrative analysis, we provide an effective means to explore the dynamics framing the processes through which MNC identity is shaped over time. Moreover, through the empirical illustration of the postcolonial nature of Pan Am narratives, the paper provides a historic deconstruction of and contextualised explanation for the multiple issues of power that still resonate in MNE actions today.

\section{Theoretical background}

\subsection{Business history and narrative analysis: a relational approach}

Although narrative analysis has made an impact within the discipline of history as a whole (Carr, 1991) its influence on business history has been much more limited (Rowlinson et al., 2014). In large part this may be due to the continued dominance of realist philosophy in business history (Durepos and Mills, 2012a) and resistance to the apparent relativism of poststructuralist historiography (Jenkins, 1991; Munslow, 2010) in which narratives can be seen as an alternative to realism (Iggers, 1997). Indeed, there is considerable ambiguity in narrative approaches to history, with some historians suggesting that narratives are constructions of real events and actors (Carr, 1991) and others suggesting that the past and history are ontologically dissonant and thus history can never be anything but a narration of an assumed past (Munslow, 2010). In the former approach narratives approximate to a real and truthful account - a single truth that is subject to modification as other evidence is unearthed. In the latter approach narratives depend on a number of factors (e.g., the storytellers, time, context and the historian) that are influenced by socio-political effects, providing a plurality of potential narratives.

The position taken in this paper, although closer to the latter (poststructural) approach incorporates elements of both approaches. To begin with, one of our starting positions is, what we call, small ' $r$ ' real. That is to say that we view the stories that are told (by those involved in events and the historians who narrate them) as having some material basis viz. Juan Trippe was the President of Pan Am for much of its early years; the textual materials produced by the airline were produced by people with a range of purposes (conscious and unconscious; deliberate and unintentional). We nonetheless reject the 
notion that narrative accounts represent or approximate to some actual historical truth. Indeed, we go beyond White (1973) and poststructuralist historiography in the argument that so-called facts depend on the narrative skills of the historian. Rather, we contend, these 'facts' also depend on the historian's interface with actor-networks (Durepos and Mills, 2012b) and the relationship of the discipline of History with public and popular histories (Kalela, 2012) - all of which provide the potential for multiple narratives. Finally, we eschew relativism for relationalism (Durepos and Mills, 2012a, 2012b; Durepos et al., 2012). While relativists contend that a lack of empirically verifiable grounding means that all (narrative) accounts are more of less equal, relationalists seek to understand narrative accounts through their empirically verifiable grounding in actor-networks (Latour, 2005).

Far from producing realist accounts of history, the relationalist (or ANTi-History) approach (Durepos and Mills, 2012a) view history as discursive rather than factual (see also Jenkins et al., 2007). To that end, we contend that the importance of history is not its representational value (e.g., based on a true story) as much as its socio-political influence in legitimising and encouraging certain values and beliefs. For example, existing histories of Pan Am (Bender and Altschul, 1982) tend to glorify men and machines to the exclusion of women and service (Dye and Mills, 2011) as if the disparities are explained away through reference to their underlying representation of the truth. A relational approach, on the other hand, would seek to understand how has a given history been produced and how does its processes of production influence people's understandings of reality? In short, we propose a sociology of historical knowledge geared to understanding how certain elements of the past come to be produced as history

\section{The research case - Pan Am}

Pan Am was a US-based international aviation company operating from 1927 until 1991. The airline is often discussed through references to its glorious and pioneering history in aviation engineering, such as the development of jet aircraft and the building of one of the earliest computerised reservation system. Even more so, Pan Am is heralded as the company that flew the largest amount of international air routes of its time: it is this multinational character of the company, with its engagement with numerous countries across the globe, which is the focus of our interest.

Since its inception, Pan Am grew to become the primary aviation company in the USA, and the most significant player in international aviation in its time. The establishment of Pan Am took place with the support of the US Government, specifically the State Department, which worked to block the airlines of other foreign powers from gaining significant position in the air routes form South America to the USA as well as helping the airline to establish air power in the southern hemisphere (Daley, 1980). In a short space of time (largely between 1927 and 1930), Pan Am's international system covered routes throughout Latin America (see Figure 2) and then on to China (1935) and other countries across the globe.

The international growth of the company and the existence of an extensive archive provides us with opportunities to deconstruct the narrative processes associated with its growth into an international system and also to reflect on how understandings of the company and the changes are shaped by its complex role in the USA. 
Figure 2 Pan Am’s routes by 1930 (see online version for colours)

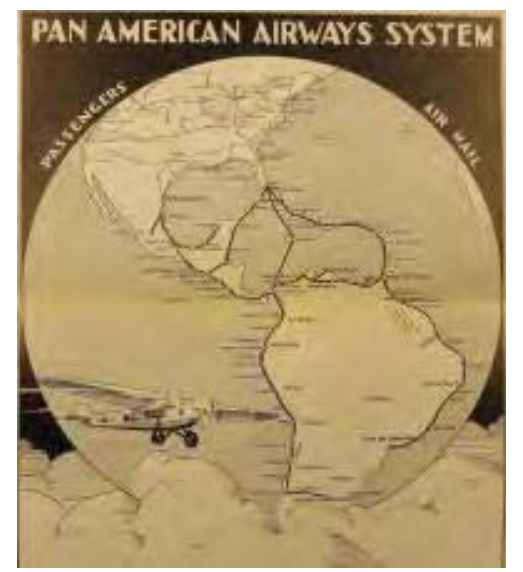

\subsection{Narratives and the study of Pan Am}

Research for this paper arose out of a much larger study of Pan Am and involved narrative analysis of several existing written histories (Bender and Altschul, 1982), other airline and aviation histories (Newton, 1978); and archived material from 'Special Collection 341 Pan American World Airways', housed at the University of Miami’s Otto Richter Library.

Our archival research entailed reading through a range of draft corporate histories and numerous other archived materials, including annual general reports, in-house newsletters, advertisements, news reports, travelogues and various other corporate materials. Essentially we were looking for various and predominant stories that the airline constructed (either deliberately and consciously or unconsciously and inadvertently) about themselves and others (e.g., nationals of the various countries served by the airline). We were interested in the stories that the airline was constructing and their socio-political impact rather than seeking out any verifiable truth.

Using a postcolonial lens (i.e., how positions of colonial dominance are created, maintained and challenged - Mignolo, 1991; Mir et al., 2008), we were particularly interested in understanding how a company of Pan Am's geographical reach and economic and political power contributed to (Western) understandings of the USA and of Latin America. To that end, we draw on historical analysis for the purposes of understanding both how history is received and understood through narratives and how narratives themselves appear to those involved as historical truths or knowledge. Thus, rather than treating the past as 'an instrument for present-day concerns' [Kipping and Üsdiken, (2008), p.113], we use the historical perspective to examine in detail the so-called effect of truths carried by historical narratives, the establishment of power relations though these narratives, and the actions such narratives help to set in motion. Kipping and Üsdiken (2008) recognise international business as one of the exceptions in management studies that have more widely applied historical research. As Scott and Christensen (1995) contend, organisations are embedded not only in current pressures but are also influenced by past circumstances. Our study continues these efforts by focusing on the role of narratives in the construction of MNE identity. 


\subsection{Multinational companies and power}

Postcolonial studies originate from Said's path-finding 1979 publication orientalism, where he explored the power structures framing European colonisers' discourse on their colonies (Young, 2001). Building on Foucault's notion of discourse, Said examined Western representations of the Middle East and its Islamic Arab peoples in European scholarly and literary writing. Among postcolonial scholars there is consensus that today Western colonialism is taking place through political, economic, and cultural hegemony, instead of the traditional expansion and territorial control. We thus join the critical and postcolonial studies in management and organisation, viewing postcolonialism as a theoretical approach that can be used in contemporary society to address the continuing imprint of the colonial legacy on the West and non-West (Prasad, 2003). We use it for the purposes of providing a 'comprehensive critique and deconstruction of the constitutive practices and discourses of neo-colonialism’ [Banerjee et al., (2009), p.8].

Postcolonial studies have entered organisation and management research during the last decade, criticising Western hegemony of management practices and discourses (Frenkel, 2008; Prasad, 2003; Westwood and Jack, 2008). Critiques of international management literature point out how mainstream international management scholars have come to depict Western corporations as the source of managerial knowledge, which is to be transferred to and replicated in local subsidiaries (Frenkel, 2008; Jackson, 2012). Postcolonial critiques have been predominantly directed at the power asymmetries that frame multinational action. While Said and others explored postcolonialiality (Amoko, 2006) through literary studies there are few analyses focusing on the discursive production of neo-colonial power relations in organisational settings (Hartt et al., 2012). The context of the multinational company provides, however, a compelling setting for postcolonial analysis.

We argue that there is lack of empirically grounded discussion of how people in multinationals develop ideas of the organisation and other organisations. There is also a lack of studies that show how these processes of portraying multinational action through power imposed on (non-Western) people as others became the taken-for-granted discourses of MNE's today. We suggest that answering these questions are made possible through historic narrative inquiry of the early multinational companies. It is through narrative inquiry that we can reach contextual understanding of the conditions (both political and economic) under which multinationals construct and enact their identity. Thus examination of the narratives evoked to produce the multinational company's action in the web of relations, may help us understand the postcolonial processes it legitimised and set in motion and how these actions were developed and self-evidently adopted by MNC's of today.

\section{Data and analysis}

\subsection{Working in the archives}

In our analysis of the Pan Am collection we focused on materials dealing with the airline's international expansion/overseas operations, which provided a means to establish understanding of how these narratives produced Pan Am's identity as an international firm. We relied mostly on company-produced materials, as our interest was 
to examine how Pan Am relates to its transformation into a multinational company through narratives. This involved analysis of such things as transcripts of chief executives' speeches, press releases by the Pan Am public relations divisional office, advertisements, annual reports, internal correspondence and minutes of meetings, and company newsletters (including the Clipper, which was the official in-house newsletter and New Horizons, which was a periodical published for the personnel of the Pan Am). However, we also included newspaper articles and published books to explain how particular versions of Pan Am's identity became widely adopted in the public narrative. Moreover, we draw on drafts of an unpublished company history, found in the archives, as illustrations of the politics involved in Pan Am's identity construction. For example, the correspondence between the author of one of Pan Am's histories and Pan Am representatives reveal how the airline's leaders aimed at sustaining particular views of the company to the public, and in maintaining control over how the story of Pan Am is to be told (Durepos et al., 2008a).

\subsection{Narrative analysis}

We take the position that narratives are very much involved in constructing identities, not only of the individuals but also of organisations (Boje, 2010; McKenna, 2010). The narrative approach, thus, can be used to explore the 'role of narrative in the social construction of historical accounts' (Bryman et al., 2011). This means that rather than looking for evidence of the historical facts (Boje, 2010; White, 1973), we seek to understand the role that stories play in constructing corporate identity and the implications for others in the organisational field (DiMaggio, 1988) and operating environments.

Narratives are produced for different audiences (Eriksson and Kovalainen, 2008), and this is particularly important when analysing the identity construction of multinational firms, which by nature are embedded in several stakeholders. Therefore, in addition to identifying the shared narrative expressed in the various documents, we recognise that the stories directed at different audiences may portray the company in different lights. Narratives include a performative element (Eriksson and Kovalainen, 2008), which leads us to ask what it is that the narratives do. Thus, in our reading of the various archival documents we sought to understand the 'functions' of the different narratives [Bryman et al., (2011), p.420], which means that our concern was not only with identifying the narratives, but what purposes these narratives served in constructing Pan Am's identity, what kinds of identity do they convey and how do they portray the company and others. We can see Pan Am's intervention in also how it tries to control the narratives constructed by others. This means that we see the power that is invested in storytelling and it allows us to point out the postcolonial nature of the identity construction, in particular.

Stories are not only a way to produce self-identity, but they also build relations to others (Eriksson and Kovalainen, 2008), and in the paper we examine, in particular, how the narrative identity constructions of Pan Am set up postcolonial relations to its international counterparts. Narrative analysis is suitable for analysing historical accounts and their development for it is sensitive to the way by which stories meld together temporal patterns and events (Bryman et al., 2011). Finally, narratives are arguably always shaped by the social context in which they are produced (Eriksson and 
Kovalainen, 2008), allowing us to expose and understand the political and other contextual processes mediating how Pan Am situates itself as a multinational company.

Our analysis is guided by the following questions: How is the identity of Pan Am produced through company narrative accounts? How do they change over time? How do the narrative identities relate to and influence the wider context of the MNE? Finally, how do the narratives serve to set up power relations?

Our narrative reading of the extensive archival materials involved, at the textual level, an analysis of the metaphoric expressions, tone, wording and other linguistic means used to portray and construct Pan Am and its relation to its international markets. The interpretative process of going back and forth between the materials and sensitising these to our postcolonial theoretical lenses, have led to the identification of the narratives involved in constructing the multinational character of Pan Am. These will be discussed in-depth in the following sections.

\section{Pan Am: a brief chronology of developments, 1927-1941}

Pan American Airways, Inc., was established in 1927 by an amalgam of three small airline companies anxious to take advantage of US mail contracts being awarded by the Postmaster General's office. The contracts were aimed at more speedy and effective mail delivery between the USA and much of Central and South America (Daley, 1980). Juan Trippe was named President and General Manager of Pan Am. The airline operated under a holding company called the Aviation Corp of America and was awarded a contract to carry mail from Miami and Key West, Florida (USA) to Havana (Cuba). In 1928 the holding company merged with another aviation holding company to form the Aviation Corp of the Americas (ACA). As we shall see below, the seemingly inconsequential adding of an ' $\mathrm{s}$ ' to the end of the name had huge consequences for how the company was positioning itself. Following the inauguration of its first commercial flight from Key West (Florida) to Havana (Cuba) in 1927, Pan Am rapidly occupied the position of number one carrier to and within South America. From the beginning of 1929 the airline expanded rapidly through acquisitions of existing airlines throughout Central and South America, starting with Compania Mexicana de Aviacion (CMA). By the end of 1929 Pan Am had also acquired Peruvian Airways, and Chilean Airways, and a fifty percent share in a new Pan American-Grace Airways (Panagra) company.

Detailing these developments in its first annual report [Aviation Corporation, (1928), p.4], the airline indicated that it had gone from one international fight (Key West-Havana) to a point where it now consisted of three 'divisions' - Caribbean (including Miami, Cuba, Haiti, the Dominican Republic and Puerto Rica); Central America (including operations in Yucatan, Honduras, Guatemala, Salvador, Nicaragua, Costa Rica, Panama, and 'the Canal Zone'; and Mexican (Brownsville, Texas; Mexico and part of Yucatan) (Aviation Corporation of the Americas, 'Annual Report', pp.4-5). The 1929 ACA Annual Report refers to the airline routes as a system serving '28 countries and colonies' throughout Central and South America, and the company thanks the US Government for 'its progressive and far sighted policy' in support of Pan Am's efforts throughout the region [Aviation Corporation, (1929), p.2]. Airline Divisions were now divided according to key operations locations, consisting of Division 
I (Miami); Division II (Mexico City and Brownsville); and Division III (Cristobal) ${ }^{1}-$ see Figures 3 and 4.

Figure 3 A crowd gather at Miami airport to greet the opening of Pan Am’s coordinated route system (January 9, 1929)

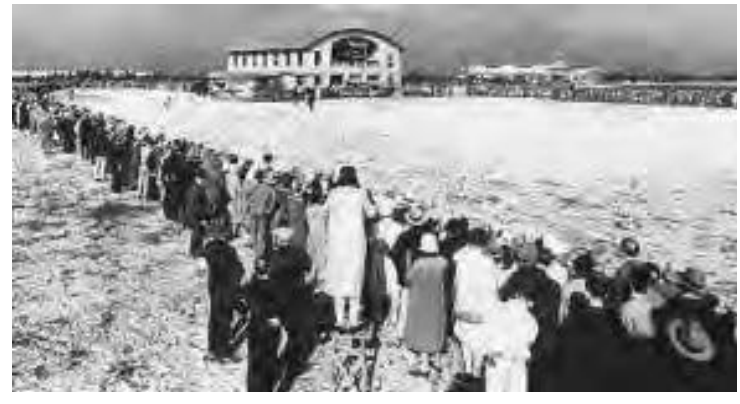

Figure 4 A Pan Am flight takes off from Miami airport

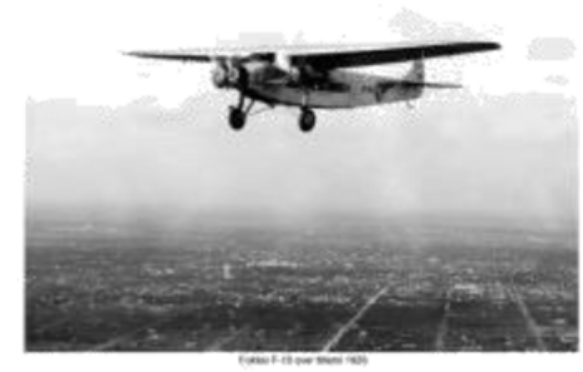

1930 saw ACA's acquisition of Sociedad Colombo-Alemana de Transportes Aéreos (SCADTA) of Colombia; New York, Rio, Buenos Aires Lines; and Panair do Brasil. They also established an operation arrangement with the British Imperial Airways, to fly into Bermuda. The annual report for the year continues to praise the US Government for its assistance and refers to the relations "between the various operating units of [the Pan Am] System and the thirty-one foreign countries to which service is available" [Aviation Corporation, (1930), p.7]. Relationships with 'foreign governments' are described as 'increasingly cordial' and reference is made to "the esprit de corps on the part of all personnel [as] already traditional, reflecting loyalty and devotion to the system and pride in its service” (ibid, pp.7, 11). By 1931, the airline was organised into Caribbean, Western and Brazilian Divisions (ibid, p.3), serving 36 'countries and colonies' over 20,664 'international' route miles, up from 251 in 1928 [Pan American Airways, (1931a), p.12, (1931b)]. The following year Pan Am's routes circled the Americas, from Brownsville (Texas) and Miami (Florida) down to Buenos Aires (Argentine) and back. 
Figure 5 The China Clipper flies over Pearl Harbour, November 1935 (see online version for colours)

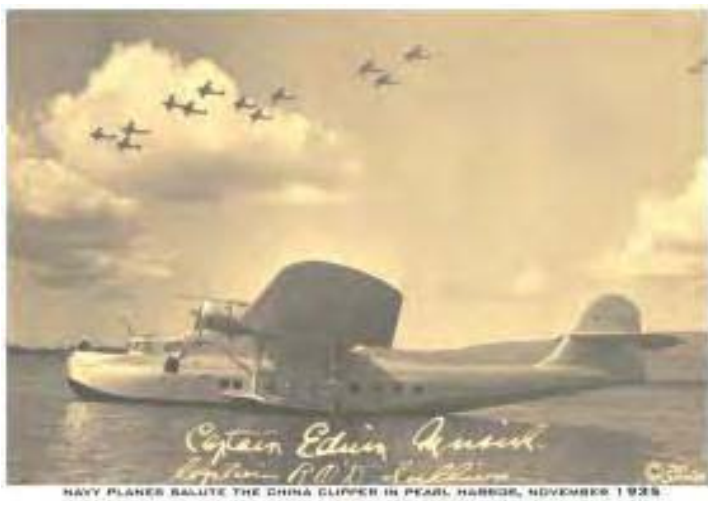

Figure 6 CNAC routes (see online version for colours)

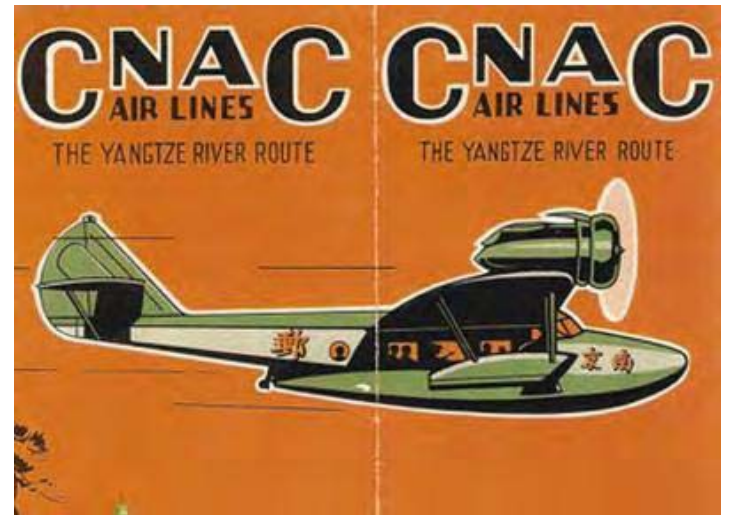

Over the next decade or so, the company continued to acquire airlines throughout Central and South America, including the Bahamas, Colombia, Cuba, Dominican Republic, Guatemala, Honduras, Mexico, Nicaragua, Panama, and Venezuela but also Alaska (1932) and China (Mills, 2006). It was also developing a range of new international routes outside of the region, starting with the acquisition of Pacific Alaska Airways in 1932 and a substantial holding (45\%) in China National Aviation Corp (CNAC) in 1933 - see Figures 5 and 6; flights from the USA to 'Australasia, via Canton Island and New Caledonia' (1940) and to Africa in 1942; and flights from South America to Europe in 1941. In 1934 the airline added a 'Pacific' Division to its existing Caribbean, Western and Brazilian Divisions (Pan American Airways Corporation, 1934) but acquisitions were moving fast and in 1935 the divisions were renamed Western, Eastern and Pacific [Pan American Airways Corporation, (1935), p.3]. An Atlantic Division was added in 1937 (ibid, p.3) but in 1943, facilitated by a shift from seaplanes to land planes, the Eastern and Western Divisions were merged to form the Latin American Division (Pan American World Airways, 1943). 


\title{
5.1 A retrospective narrative history
}

On 1 January 1942, the Public Relations Department of Pan Am's Eastern Division developed, what it called, a 'Story of the Eastern ('Mother') Division. Pan American Airways System, 1927-1942'. It is not clear why the 39-page story was developed but a later commentator has speculated that it was 'propaganda' geared to the onset of World War II and the potential for US involvement (Pan American World Airways, 1942). From the very opening the story attempts to establish Pan Am's roots as pioneering of the most dramatic kind, likening the airline to the Spanish conquistadores and painting a picture of an undiscovered terrain below the borders of the USA. It sets up the notion of Pan Am as a heroic, pioneering, technologically advanced, and international company and its neighbours to the South as passive, backward, in need to help and discovery:

\begin{abstract}
"The old-time explorers, the bloody conquistadores driving their conquests through virgin lands with sword and flame, the hardy pioneers of both Americas slashing their settlements out of the wilderness - these are well matched by the Americans of 1927 and succeeding years who pushed the pioneering inter-American airline from Florida south, throwing the great loops of the international 'railway lines of the air' around and across the Caribbean sea, over the rough reaches of Mexico and Central America, down the Pacific coast, over the lofty Andes, barrier of the ages, and around the great South American continent. These great tasks with all their complicated detail called for pioneering of a type similar to that which has marked all the world's great periods of progress.”
\end{abstract}

\subsection{The pioneer of international airways}

As fanciful as the public relations' story is it was arguably developed from numerous Pan Am narrative accounts over the years. Throughout the reading of Pan Am materials there is evidence of a meta-(or all-encompassing) narrative that constructs the airline as a heroic, pioneering, technologically advanced and international company.

As early as February 1930, in the first volume of its Pan American Air Ways newsletter, the airline told employees, "Pan American is greatest operator of big airlines" and "P.A.A. [Pan American Airways] leads the world" [Pan American Airways Corporation, (1930), pp.1, 6]. This particular story cites evidence that Pan Am is the "world's largest commercial operator of multi-engine transport planes and the largest unified air transportation system in the western hemisphere" (Ibid). This story praised Pan Am's technological advantage as globally unique, and also constructed the company's international might. The narrative is one of many over the years that highlight Pan Am's introduction of groundbreaking innovations that provide even faster access to remote areas. Elsewhere the company was already developing the theme of being a world-beater or world best, with references to the 'world's greatest air transport system' (Pan American Airways, 1930b). These stories show Pan Am's identity as an international company that is rooted in this overarching story of a pioneer and leading company in international aviation.

One of the airline's earliest references to its 'pioneering' role can be found in a 1930 edition of its newsletter. Although the headline - 'Pioneer?' - appears to question its status the article goes on to state that "three years ago we started of a great and romantic venture [that] captured the imagination of the public, the editor, the business man. Today we have arrived” (Pan American Airways, 1930c). It goes on to detail its technological 
feats and its geographical reach. A similar story is told to the shareholders through the pages of the 1930 Annual Report and references to 'considerable pioneering extension and development work’ [Pan American Airways, (1931a), p.11].

Interwoven through its narrative Pan Am also portrayed itself as a company that was jumping from one success to another as a pioneer in every field it entered, being the "first US airline to pioneer and develop over-ocean flying, the first to work with manufacturers in developing a number of plane types, ... the first to unite [through air service] the US and strategic Alaska ... [and] the first airline system to introduce modern flight procedures in Latin America ...” (Pan American World Airways, 1944). This was a powerful, dominant narrative of the firm, which eventually became reproduced and supported, produced, and hailed by external voices such as the newspapers.

This pioneering nature was seen as one of the causes for its international success. Since its inception in 1927 Pan Am rapidly developed its international network and hence its identity relied heavily on notions of being an international company. This identity is constructed by claiming that 'P.A.A. leads world'. Pan Am was frequently cited as the 'leading' airline. The unique dominant character of the airline is enforced through comparisons to competitors (e.g., references to 'no other airline' can compare with Pan Am in many key areas of aviation). Not only was Pan Am recognised for having the widest international routes in Latin America, but it was also cited that its routes and number of aircraft outran all foreign competitors.

However, the multinational character of the company would come to mean that its identity construction is multifaceted by nature, and through our analysis we explored what kinds of narratives were generated to explain and construct Pan Am as an international airline. The international aspects of the company necessitate the construction of different narratives that appeal to the different stakeholders of the multinational firm.

\subsection{Airline of the Americas}

Pan Am became renowned for its wide routes in Latin America. However, from the beginning there were questions about its role and relationship with the US Government. There is little doubt that, in a number of ways, the airline served as 'the chosen instrument of US State Department policy' in Latin America (Bender and Altschul, 1982). Nonetheless, in order to position itself as an international company - attracting passengers not only from the USA to Latin America but also from Latin America to other Latin American countries and to the USA itself - it also carefully worked, on occasion, to present itself as politically neutral.

Trying where possible to show its development role as working through and with Latin American Governments, the airline often presented itself as the 'Airline of the Americas' in which it attempted to appear to be politically neutral. Thus, for example, in the 1929 Annual Report the airline's efforts to acquire a number of Latin American airlines is described as "a community effort on the part of the United States aviation industry to extend safe and reliable American air transport service to the foreign field" [Aviation Corporation, (1929), p.4]. It then goes on to claim that "28 countries and colonies have co-operated in the establishment of this international service...” (Ibid, p.4).

On various occasions the airline would stress direct cooperation with the leaders of various Latin American countries. For example, in 1932 Pan Am reported on its 
acquisition of Cuba's national airline, citing the support of Cuba's "President Gerardo Machado [as having] championed the establishment of modern air transportation in Cuba" [Pan American Airways, (1932), p.4]. Two decades later airline President Juan Trippe praised Eva Peron, wife of Argentinian President Juan Peron, for christening the company's Clipper Friendship plane, citing this as "the newest evidence of the close ties that exist between [the United States] and Argentina” (Pan American Airways, 1950) - see Figure 7.

In private, Pan Am executives were concerned that the airline's image would become overly associated with the US State Department rather than with Americanism as a whole. In an early report, speaking to employees through Pan American Air Ways senior managers stated that “our real job ... isn't just busy running an air line ... but is the bringing together into happy, profitable relationships, the seventy-five millions of South America and the hundred and fifty millions of North America... Pan American Airways System is not just a United States company. It is a national company in each country it serves and becomes more so as its service is of greater value" (Pan American Airways, 1930a). However, this emerging narrative of the airline's international character had a political nature, built out of concerns of reducing potential worries throughout the region that Pan Am would be seen as primarily serving US national interests. In striving for, at least the appearance of, political neutrality, the discourse of internationality provided a good opportunity. In building the truly international airline Pan Am adopted the rhetoric of talking about the company as an 'international system', which helped to frame the company as a unified front bringing together the Americas and include the welfare of its South American affiliates. It was cited as the airline of the 'Americas', and there was equality with 'sister governments'. The rhetoric employed in these narrations highlight the equality of the US-based Pan Am and its international markets.

Nonetheless, the narrative served to obfuscate Pan Am's expansionist role in which it worked through local dictators (starting with Cuba's Machado through to Argentina's Peron) to establish control of local airlines and its illegal activities in the acquisition of national airlines in Mexico and Colombia despite those countries laws against foreign ownership of their airlines (Daley, 1980).

With the defeat of Herbert Hoover in the US elections of 1932 Pan Am's internationalist narrative was somewhat strengthened with the election of Franklin Delano Roosevelt and his adoption of the 'good neighbour' policy. The policy became known for its aims of non-interventionist foreign policy, particularly in the Southern Hemisphere and Latin America, and to create reciprocal trade relations with the other American republics (Patel, 2015). This policy provided a setting from which we can see the rise of the all-American identity of Pan Am. The academic research published during WWII also recognised Pan Am as a company that was 'serving inter-American needs' [Lockwood and Smith, (1941), p.676]. During this time we can see Pan Am's international narrative becoming even more centre-stage in its telling and presentation throughout company materials. The narrative serves to combat potential counter-narrations on the company's imperialist conquest by emphasising national freedom. As a part of the 'international system', Pan Am is 'handing power' to the nationalised affiliates. Pan Am declares that 'our real job' is to be a national company in every market, to seek friendship and equality. Pan America's role as an integrator is stressed as Pan Am states that through its airline routes the barrier between north and south are removed for the first time. These helped to portray the company in a favourable light. This narrative is supporting the idea of the airline of the Americas and reproduces 
the multinational firm as a nationally and politically independent actor. The use of this narrative can be seen as a way to silence any potential counter narratives that might voice critique against Pan Am's treatment of the South American markets.

The narrative construction of the All American identity was supported through three interlinked storylines/sub-narratives that constructed Pan Am's identity as the moderniser, the barer of social welfare, and an agent of cultural integration - see Figure 7.

Figure 7 Pan Am President Juan Trippe looks over his empire

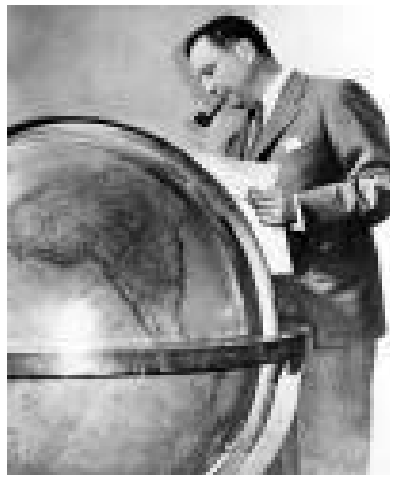

\subsubsection{The moderniser}

The first of these portrayed Pan Am as the one who would bring modernity to the South American markets in which it operated. For example, Pan Am's 1943 involvement in 'setting up of operations of the newly formed Aerovias Venezolanos, S.S. airline, (Avensa)' is described as being 'called in to contribute its 'know-how' on technical organisation' - adding that it was also participating as 'a minority stockholder' [Pan American Airways, (1943), p.13]. The stories employed aviation technology as the metaphor for modernity. By spreading the technological advances to others, Pan Am is modernising them and offering them access to the need that local 'business men' must have. Aviation technology is constructed as the means that provides each market the opportunities to meet the requirements of modern business life (e.g., provides the Latin American businessmen the rapid mode of transportation that they supposedly need in the hectic business). Also the notions that Pan Am offered training and modernisation opportunities were widely used arguments in the narrative. Lockwood and Smith (1941) acknowledge that the training and technical assistance offered by the USA to other American republics was an important contribution to hemispheric prosperity. They also claim that the programs initiated by Pan Am involve 'the most ambitious program' (ibid, p.679). By spreading the aviation gospel Pan Am narratives simultaneously sustained the taken-for-granted notions that US technology is vital for the development of Latin America - see Figure 8. The story is embedded with the underlying assumption that Latin American markets are following the Western trajectory of development and modernisation, and that the development process can be achieved through the support from Pan Am (this relies very much on the same rhetoric that has been used to legitimise and justify multinational corporations operations today in the developing and third world 
countries). Accordingly, Pan Am is positioned as the aviation expert, who will transfer its knowledge to the subsidiary firms (placing Pan Am in the lead of the Latin American markets' development). The superior aviation technology possessed by Pan Am is enrolled as a vehicle in spreading the latest aviation technology to the international markets and setting their development in motion. This narrative has parallels to contemporary postcolonial critiques that consider globalisation as a major driving force that sustains the power divide created in the colonial era, as it diffuses Western culture and capitalist society (Banerjee and Linstead, 2001) and overall Western control of the global economy (Frenkel and Shenhav, 2006).

Figure 8 Pan Am in old Cuba (see online version for colours)

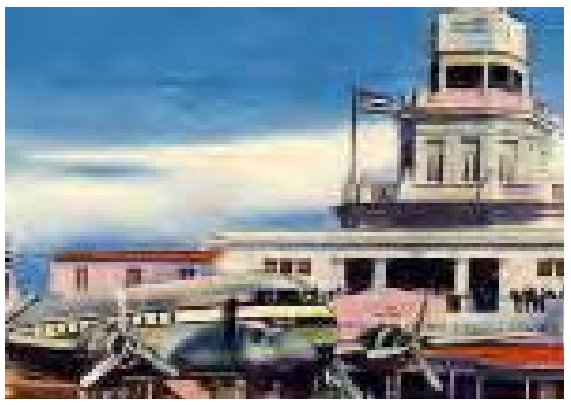

\subsubsection{The social actor}

Secondly, the 'de-politicised' character of Pan Am was further supported by highlighting its social roles in the sister markets. It highlighted the social good and benefits that are brought by Pan Am to the local markets: In "its role as a good citizen of the countries it serves, Pan American has been both counselor and helping hand in the formation of a dozen Latin American airlines” [Pan American Airways, (1957), p.4].

The sub-narrative was constructing Pan Am as a socially responsible actor and it lends itself to what has today come to be known as corporate social responsibility, which is one of the major themes in debates on multinational corporations (Banerjee, 2007). This involved not only bringing them economic prosperity but also introducing social and cultural benefits. Multinational companies today play with similar images (ibid).

\subsubsection{The integrator of cultures}

Finally, the creation of all-American identity was derived from the storyline of cultural integration. Pan Am assumed the position of a node between the North and South:

Probably nowhere in the world has air transportation made such an important impact on culture and economy as in Latin America - the birthplace and cradle of Pan American. Just as railroads played the key role in unifying and developing the United States, it was the airplane - which could soar over sea, mountains and jungles - that played the same vital part in bringing together the American nations. From its start as the pioneer in the field of international transportation, Pan American has emerged as the largest operator of air transportation in Latin America today. It's career over the past three decades aptly illustrated the advancement in making true neighbors out of the world's peoples. [Pan American Airways, (1957), p.1-2] 
The pioneering role is recited here, now claiming that Pan Am is the first airline (and, by implication, the first organisation) to link North and South (see Figure 9). The narrative puts forth the idea that companies can act as messengers of globalisation. Pan Am was portrayed as uniting people, and even educating people on cross-cultural issues. Constructing Pan Am as an agent of cultural awareness involves claiming that Pan Am provides two-directional cultural education, allows it to unify North and South America, bringing people together and across any cultural boundaries that may exist. The story makes use of the international trope to characterise Pan Am as an international company that provides people the opportunity to reach out to other cultures and learn about them ${ }^{2}$ (see Figure 10).

Figure 9 Pan Am's integration of north and south (see online version for colours)

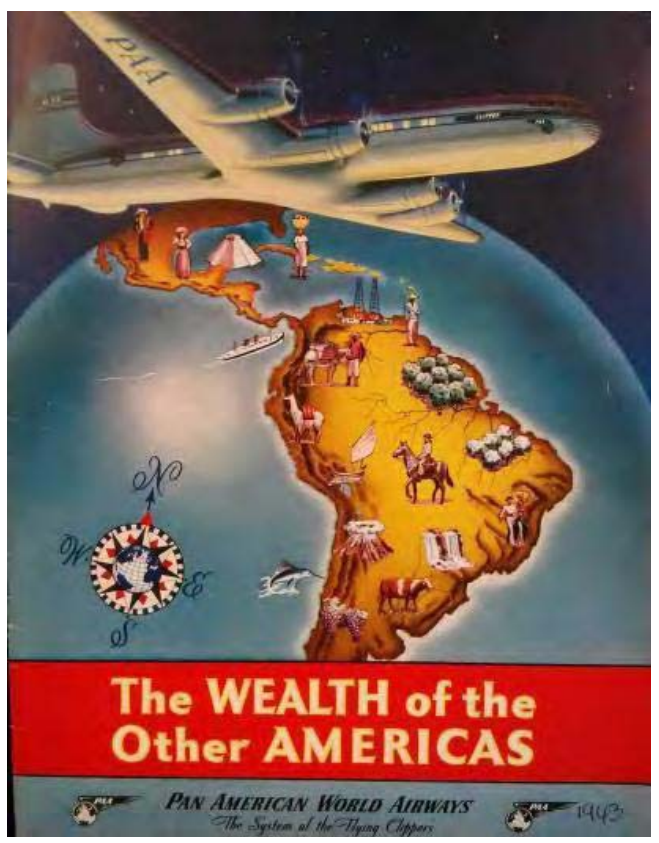

From a postcolonial perspective, these metaphors however construct hierarchical relations of interdependency and dominance, positioning Pan Am (and behind it the USA) as having experienced and presumably learned from unification to be able to assist the Latin American countries. In this positioning Pan Am was a forerunner in the development of the idea of the MNE as a socially useful force in the world.

To conclude on the nature of the 'all American' narrative, it aimed at justifying Pan Am's international acquisitions through maintaining national control, modernisation of locals and improved service, as well as the increase of social welfare and cultural richness. 
Figure 10 A Pan Am view of exploring other cultures (see online version for colours)

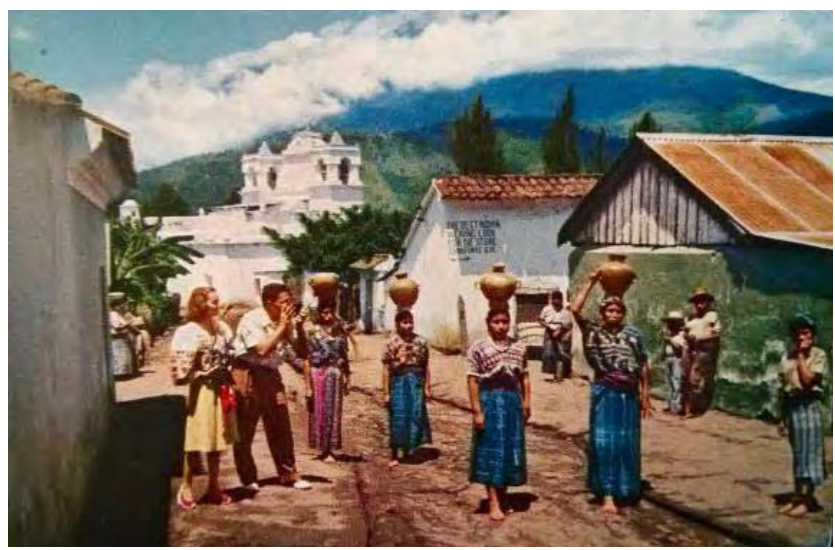

\subsection{The US story of success}

Whereas most of Pan Am's narratives were driven by the desire to appear detached from any nationalist, political interests, there were other contradictory narratives being produced by the same company. This was particularly evident in the narrative of organisational success. This narrative tells about a US company that has the business acumen to conquer new markets and become a dominant force in its operating markets - a dominance that Pan Am could hardly refrain from linking to the notion of Americanism (Hartt et al., 2012). See Figure 11.

Figure 11 Pan American and Americanism (see online version for colours)

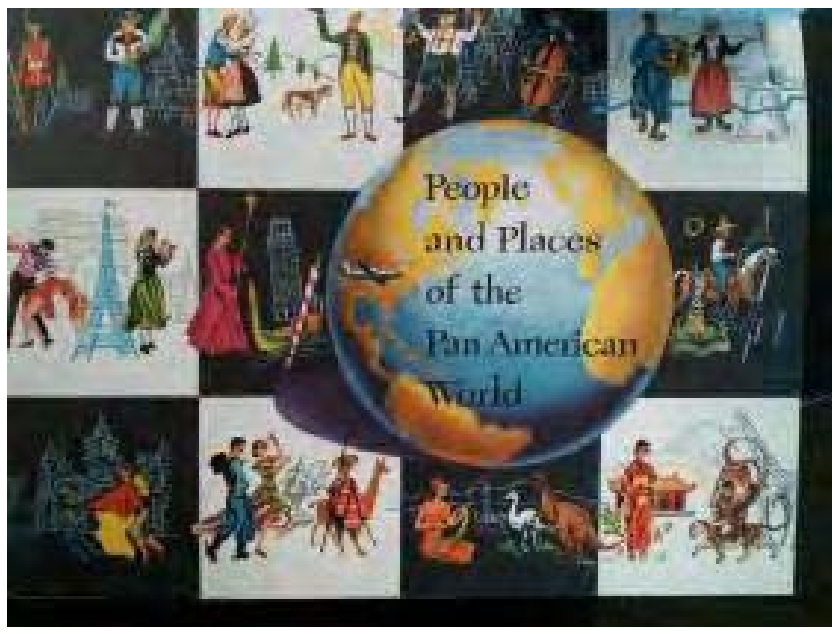


When reciting and identifying the process through which Pan Am grew into one of the largest airlines in the world, the narratives draw on national sentiments and postcolonial imagery. The narrative underscores Pan Am's business acumen, and its determination to achieve international expansion. In this story the expansion becomes told as a conquest, and Pan Am's role as a source of US national pride is centre-stage. The national sentiments and political linkages are apparent here (see Figure 12):

\begin{abstract}
Air express service for the shipment of good between the United States and seventeen Latin American countries was inaugurated on June 4th by the Pan American Airways... In the interest of American business, which for several years has stressed the need for a rapid and dependable means of transport for export merchandise, the study of air express through the many countries served on the international airway was undertaken. After two years of pioneering and research the system has been perfected to the point where it can function to these seventeen countries with the same reliability and efficiency that have distinguished the US international mail service. [Pan American Airways, (1931b), p.129, 132]
\end{abstract}

Figure 12 Pan Am a world leader (see online version for colours)

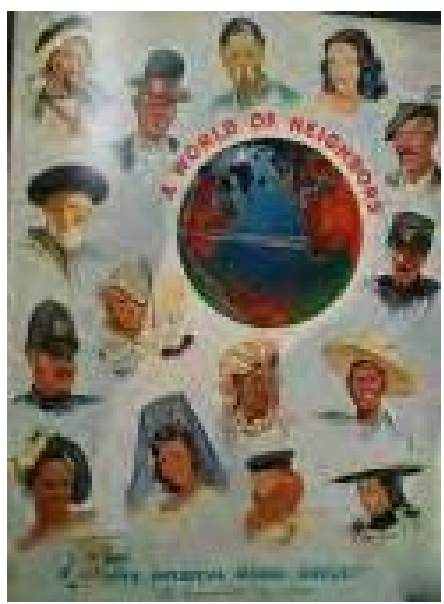

The narration highlights Pan Am as a leading company, which through its unprecedented determination and speed acquires new flight routes to its international system. This narrative on Pan Am's internationalisation process serves, we argue, to sustain the colonising project in which colonies have traditionally been assigned to the role of "providing resources to enable the development of Western economies rather than industrializing in their own right” [Young, (2001), p.49] - see Figure 13. Pan Am is represented as a calculative, rational actor, targeting international markets according to its needs. Its evaluation of the potential partners was an outside process, objectifying the partners (they could be replaceable). Altogether, the management of foreign operations and the conduct of international strategies are typically built upon the 'home-centric mindset', where home-based organisations execute and oversee operations in the target market thus underlining the 'us versus them dichotomy' (Brannen and Doz, 2010, p. 238). Pan Am thus legitimised and naturalised its own focal power position. 
Figure 13 Postcolonial imagery (see online version for colours)

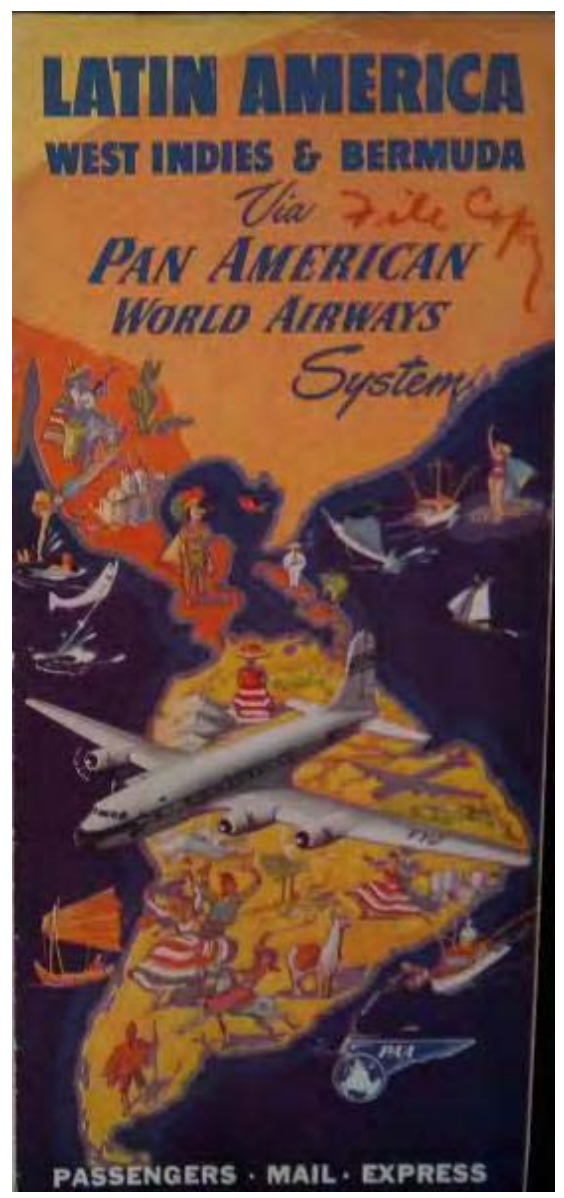

\section{Discussion and conclusions}

As we stated at the beginning of this paper, our interest in organisational narratives is focused on how Pan American Airways positioned itself as a multinational company through the use of storytelling and what are the implications for:

1 the countries in which the airline operated

2 our understanding of narratives and the role of the MNE

3 the implications for history making.

We will discuss each in turn. 


\subsection{Narratives, company history and context}

We drew on postcolonial theory (Said, 1979; Young, 2001) to critically examine the narratives produced by Pan Am. Through extensive archival research ${ }^{3}$ we examined a wealth of materials to try to understand if and how Pan Am drew on storytelling to create a powerful image of itself and, in the process, of its history. We were able to identify three powerful but contradictory meta-narratives - the pioneer, the all-Americas company and the successful US multinational. Nonetheless, each narrative arguably served to establish the notion of Western (in this case, specifically Northern) supremacy and laid the ground for later postcolonial notions that have permeated corporate histories. Postcoloniality (i.e., Western representation of the 'other') is inherent in each of Pan Am's major narratives. The professed pioneering role evokes images of Western progress over more primitive peoples and lands. The all-Americas role evokes the idea that the peoples of Latin America need and can be helped (by a benevolent Western company) to achieve not only economic and political progress but also much needed integration and a civilising force. Through both narratives we can see reference to the successful US company whose very successes speaks to the superior experiences and knowledge of US citizens operating in Latin America. Through these narratives we glimpse contrasting images of the North American (from the USA) and the 'idea of Latin America' (Mignolo, 1991). Created not so much through the kind of literary images that Said (1979) focused on but the powerful storytelling and associated practices of companies such as Pan Am and the United Fruit Company.

\subsection{Pan Am as Precursor of the modern MNE}

As discussed earlier, the narratives of Pan Am back in the first half of the 20th century may well have contributed to the development of the idea of the multinational over time, with an influence through to todays' MNE's (Westwood and Jack, 2008). We underscore, that through historic analysis of the development of these narratives in a particular socio-politic and economic setting, we can read into the roots and possible explanations of these narratives (how they were constructed to secure the company's identity in the global turmoil) as well as highlight some of the far-reaching consequences (the naturalisation of projecting postcolonial images of the other and dominant position of the MNE over its subsidiaries, in particular). The narratives about Pan Am show how the company was considering its multiple stakeholders, the US Government, its employees, and the governments and people in the international markets. Present day research has made similar illustrations of the multifaceted nature of multinational identity construction [e.g., Vaara and Tienari (2011) note based on narrative analysis how a merging financial services group emphasised Nordic interests and equality of the Scandinavian countries involved as a means to legitimise the merger].

\subsection{Narratives as/and history}

We examined selective dominant narratives that were generated about Pan Am (e.g., histories and how they present Pan Am), and this leads us to highlight what role do narratives play in the development of company histories, and discuss what kinds of, effects narratives have on the various peoples that the airline dealt with. We highlight that 
from the perspective of the MNE the narratives were helpful in portraying its actions in a positive light. Today, storytelling on success has come to be an inherent part of the genre of corporate history, in which "innovation, change or pioneering products or managerial methods drive the narrative forward as the company grows from strength to strength" (Delahaye et al., 2009). For Pan Am, especially the narrative of the heroic, pioneering, all-Americas character helped to develop company history in ways that helped to reduce resistance from the local governments.

However, from another viewpoint, these narratives created and naturalised a postcolonial relation. The all-Americas narrative highlighted the role that Pan Am as an international company takes in (what has become known as) globalisation and transcending cultures. In spite of the aims of this narrative to construct a sense of mutual appreciation of cultures and equality, the narrative produces a direction from the North to the South. It helps to sustain the hierarchical notions and the idea that the others will be helped to modernisation. Thereby Pan Am was portrayed as conducting the global project, bringing both modernity as well as social benefits.

Our focus on company-produced narratives unavoidably represents 'formal' narratives of the firm (Boje, 2008). This may explain the need to produce different versions of the company to please the company's various stakeholders both in the US terrain and it various international markets. Our findings illustrate that narratives provide an effective means for Pan Am to sustain the heroic image of the company in the eyes of different audiences. While the company tried to portray itself as an all-Americas company that has the interest of its international collaborators in mind, the postcolonial reading of the narrative brings forth the problematic nature of these stories. Specifically, in spite of the multi-sidedness of the narratives, they all convey the centrality and heroic nature of the multinational company in ways that silenced other versions of the company identity. In particular, these forms of presentation marginalise the 'international system' (Pan Am's own rhetoric to describe the company) and fail to produce a space where the voices of the subsidiary firms would be heard.

The findings derived through archival research methods lead us to ask how the narratives of the multinational company produced in the past to construct its position as an international company could be used to understand some of the complexities framing multinational action even today. As we know from the postcolonial critiques presented toward today's multinational companies, the postcolonial narratives and actions once put forward by Pan Am (and other early MNE's) have become widely taken-for-granted notions for multinational action (see for example, Banerjee, 2007; Banerjee and Linstead, 2001).

Through understanding the history of MNE's we can understand the situational factors that led to a postcolonial set up at those times (e.g., the political environment in the USA immediately prior to WWII and into the Cold War era). However, we need to start asking questions as to how we can avoid repeating and sustaining these notions and produce MNEs that are more equivocal. To find solutions one needs to ask, for example, how could the company narratives told by MNE's be developed in ways that include other actors rather than the focal firm alone? Future studies from a business historical perspective could seek to explore various archives for the Others' voice, and examine how they co-produced Pan $\mathrm{Am}^{4}$ or indeed produced ante-narratives (Boje, 1991). It is by hearing and investigating the stories of the 'others' in the MNE network that we can take forward the ideas of how the dominant narratives can be resisted through their deconstruction and the development of alternative narratives (Krysa et al., 2016). 
Analyses of company histories of Pan Am suggest a powerful role for narratives in their construction. At one level we have the narratives themselves that are embedded in each particular history. As White has already explored in great depth, histories can be view as narrative accounts of events (White, 1973). Thus, White goes on to suggest that each history draws on powerful (Western) narrative style of romance, comedy, satire, and tragedy in the telling (White, 1984). Much of the history of Pan Am is written in the romantic style, with Juan Trippe as the inevitable hero: most of the Latin American leaders are but players in the story of Juan Trippe. The airline itself is also cast as a heroic figure - that of the pioneer company that triumphs in the face of adversity. Many of the same histories also contain a strong comedic element of Pan Am as a unifying force (Bender and Altschul, 1982; Daley, 1980; Turner, 1976). In one case a satirical approach is taken as the forces for good are seen as containing the seeds of destruction (Josephson, 1943). In at least one other history the story is told as tragedy (Gandt, 1995). Drawing on the debates around the role of narratives in history we might ask whether, regardless of style, if historical narratives are re-presentations of factual events, fictional accounts, or somewhere in between (Carr, 1991)? Certainly each historical account draws on a series of people and events whose time, place and utterances are subject to verification. However, as White contends, which 'facts' are focussed on and how stories are constructed around those 'facts' depends on the constructions of narratives by the respective historian (White, 1987). So, at the very least, there is an element of fiction in each attempt at representation.

If we move to the organisational level there are also the narratives that were generated by the airline itself - often romantic and comedic, sometimes tragic (especially in the post-war era when it faced competition on many of its previously monopoly routes), and sometime satirical (as the airline responded to what it saw as government inspired negative changes to the airline industry). Few historical accounts, if any, can avoid the influence of organisational storytelling (Boje, 2008). Analysis of existing histories of Pan American Airlines indicates that all of the company-generated narratives were drawn on to develop accounts of the airline's history. These may have been viewed through the prism of objectivity but they nonetheless serve to influence and shape the direction of the written histories.

This brings us to a third level, the narrative influences of public, popular and disciplinary historical accounts on the historian. As Kalela (2012) argues, the historian does not start with a blank slate. He or she has some sense of a company (person, or event) before they start out to write a history. That sense, again held up to the prism of objectivity, is nonetheless influenced by a series of powerful stories about the subject of each history. For example, to what extent is our understanding of Pan American Airways influenced by such things as public hearings of the companies activities, movie (and recently television) accounts of the company, novels (see for example Follett, 1991) and existing histories? And how are we able to objectively account for their influences? That brings us to yet another level - audience. How far are historical accounts influenced by powerful meta-narratives (Lyotard, 1993) and specific audiences within those meta-narratives (Foucault, 1965)? For example, accounts of big business during the Depression in the USA were arguably influenced by widespread hostility to big business organisations. A similar focus on big business during the Cold War era arguably encouraged a 'rewrite' of history to move the story of big business from that of Robber Barons to a vitally important and positive force in the development of the USA (Lemisch, 
1975). Carr (1991) adds to the debate in the contention that narrative accounts are not simply devoid of reality but are somehow related to what he calls the pre-theory or pre-narrative state of lived experience, i.e., the influence of storytelling on people's sense of self and events. He suggests that the development of narratives be they at corporate or disciplinary level (i.e., the writing of history), somehow build on the fragments of storied accounts of people as they express their lives.

Finally there is some evidence of a powerful socio-political layer where narratives are influenced by networks of actors who enrol others to a specific way of viewing knowledge (Munslow, 2010), specifically 'knowledge of the past' (Durepos and Mills, 2012a). Lemisch (1975), for example, has shown how eminent US historians have acted to naturalise a focus on big business during the Cold War, literally rewriting history in line with newer dominant discourses. More specifically, Durepos et al. (2008a) has revealed how a group of powerful corporate actors influenced the development and shaping of a heroic account of Juan Trippe and the development of Pan Am. An important influence on the socio-political writing will depend in large part on archives of materials. Who and why the materials are collected are not inconsequential to the histories that get told (Mills and Mills, 2011). This is particularly important for postcolonial analysis where the voices of the 'other' are missing (Decker, 2013) Like Decker (2013) we found the voices of the Latin American 'other' missing from the Pan Am archive. What we did find were numerous accounts told through the official and semi-formal accounts of senior managers and certain employees. We also found considerable written accounts and interviews that had been developed/collected by a historian hired by the airline to write a corporate history. That history was never fully developed or published but much of it found its way into subsequent histories. Our treatment of the narrative accounts was influenced by the following approach:

1 we adopted a postcolonial lens to view the potential impact of the found narratives on the production of the MNC and 'the idea of Latin America'

2 we treated the corporate narratives as evidence not of a history of the company per se but rather of a way of thinking

3 we treated the material and our own narrative (surely satirical in style) in a reflective manner, which encourages the reader to treat our account - as all such accounts - as a history of sorts.

The purpose of this paper was to examine how - using a postcolonial lens - multinational identity is produced in historical narratives. To achieve this goal, we presented a narrative analysis of the Pan Am and how it constructed itself as an international company. While we claim that narratives are a worthy and useful focus for understanding corporate identity and its influence on various actors, we do not claim that all MNE's - then or now - follow a similar trajectory. What we are contending is that in the ability of the MNE to maintain a successful image across its various jurisdictions it is a useful exercise to study the role of narratives over time. Such narratives, we conclude, are not simple inventions of the publicity departments of MNE's (although invariably some are) but are rather complex stories that arise in response to various pressures and come to constitute not a history of the organisation but rather powerful (but inevitably flawed) stories that work (where they do work) in tandem with material practices.

In summary, we have tried to understand the various uses of narrative by early MNE's and the outcome for the peoples of the countries they interact with, in particular 
the development and maintenance of postcoloniality. Recent evidence suggests that MNE's operating in so-called developing countries often use a mixture of narratives to position themselves as 'good employers' of local labour and good international citizens while, paradoxically, contributing to imagery of western superiority (Banerjee, 2007). Banerjee and Linstead (2001) argue that this imagery constitutes a modern form of colonialism, replacing literary stories of western imperialism (Said, 1979) with western narratives of business knowledge. In the words of Banerjee et al. (2009, p.8), the narratives of the modern MNE and their associated hiring practices are 'constitutive practices and discourses of neo-colonialism' and inhibit 'organisational knowledge transfer’ [Mir et al., (2008), p.203].

\section{Acknowledgements}

This research has been funded by the strategic funding of the University of Eastern Finland, the Foundation for Economic Education, and the Social Sciences and Humanities Research Council of Canada \#435-2013-0483.

\section{References}

Amoko, A. (2006) 'Race and postcoloniality', in Malpas, S. and Wake, P. (Eds.): The Routledge Companion to Critical Theory, pp.127-139, Routledge, London.

Aviation Corporation of the Americas (1928) Annual Report, New York.

Aviation Corporation of the Americas (1929) Annual Report, New York.

Aviation Corporation of the Americas (1930) Annual Report, New York.

Banerjee, S.B. (2007) Corporate Social Responsibility: The good, the Bad and the Ugly, Edward Elgar, Cheltenham, Glos, UK; Northampton, MA.

Banerjee, S.B. and Linstead, S. (2001) 'Globalization, multiculturalism and other fictions: Colonialism for the new millennium?’, Organization, Vol. 8, No. 4, pp.683-722.

Banerjee, S.B., Chio, V.C.M. and Mir, R. (2009) 'The imperial formations of globalization', in Banerjee, S.B., Chio, V.C.M. and Mir, R. (Eds.): Organizations, Markets and Imperial Formations: Towards an Anthropology of Globalization, pp.3-14, Edward Elgar Publishing, London.

Bender, M. and Altschul, S. (1982) The Chosen Instrument: Pan Am, Juan Trippe, the Rise and Fall of an American Entrepreneur, Simon and Schuster, New York.

Boje, D. (1991) 'The storytelling organization: a study of story performance in an office supply firm', Administrative Science Quarterly, Vol. 36, No. 1, pp.106-126.

Boje, D.M. (2008) Storytelling Organizations, SAGE, London; Thousand Oaks, California.

Boje, D.M. (2010) 'Narrative Analysis', in Mills, A.J., Durepos, G. and Wiebe, E. (Eds.): Sage Encyclopedia of Case Study Research, Vol. 2, pp.591-594, Sage, Thousand Oaks, CA.

Booth, C. and Rowlinson, M. (2006) 'Management and organizational history: prospects', Management \& Organizational History, Vol. 1, No. 1, pp.5-30.

Boussebaa, M. and Morgan, G. (2014) 'Pushing the frontiers of critical international business studies: the multinational as a neo-imperial space', Critical Perspectives on International Business, Vol. 10, Nos. 1-2, pp.96-106.

Brannen, M.Y. and Doz, Y.L. (2010) 'From a distance and detached to up close and personal: bridging strategic and cross-cultural perspectives in international management research and practice’, Scandinavian Journal of Management, Vol. 26, No. 3, pp.236-247. 
Bryman, A., Bell, E., Mills, A.J. and Yue, A.R. (2011) Business Research Methods, 1st Canadian ed., Oxford University Press, Toronto.

Carr, D. (1991) Time, Narrative, and History, Indiana University Press, Bloomingdale, Indianapolis.

Daley, R. (1980) An American Saga. Juan Trippe and His Pan Am Empire, Random House, New York.

Decker, S. (2013) 'The silence of the archives: business history, post-colonialism and archival ethnography’, Management \& Organizational History, Vol. 8, No. 2, pp.155-173.

Delahaye, A., Booth, C., Clark, P., Procter, S. and Rowlinson, M. (2009) 'The genre of corporate history', Journal of Organizational Change Management, Vol. 22, No.1, pp.27-48.

DiMaggio, P. (1988) 'Interest and agency in institutional theory', in Zucker, L.G. (Ed.): Institutional Patterns and Organizations, pp.3-22, Ballenger, Cambridge, MA.

Durepos, G. and Mills, A.J. (2012a) Anti-history: Theorizing the Past, History, and Historiography in Management and Organization Studies, Information Age Pub, Charlotte, NC.

Durepos, G. and Mills, A.J. (2012b) 'Actor network theory, anti-history, and critical organizational historiography’, Organization, Vol. 19, No. 6, pp.703-721.

Durepos, G., Mills, A.J. and Weatherbee, T.G. (2012) 'Theorizing the past: realism, relativism, relationalism and the reassembly of Weber', Management \& Organizational History, Vol. 7, No.3, pp.267-281.

Durepos, G., Mills, J.H. and Mills, A.J. (2008a) 'Flights of fancy: myth, monopoly and the making of Pan American Airways', Journal of Management History, Vol. 14, No.2, pp.116-127.

Durepos, G., Mills, J.H. and Mills, A.J. (2008b) 'Tales in the manufacture of knowledge: writing a company history of Pan American World Airways', Management \& Organizational History, Vol. 3, No. 1, pp.63-80.

Dye, K.E. and Mills, A.J. (2011) 'Dueling discourses at work: upsetting the gender order', Canadian Journal of Administrative Science, Vol. 28, No. 4, pp.427-439.

Ellsberg, D. (2002) Secrets. A Memoir of Vietnam and the Pantagon Papers, Viking, New York.

Eriksson, P. and Kovalainen, A. (2008) Qualitative Methods in Business Research, Sage, London.

Follett, K. (1991) Night over Water, MacMillan, London.

Foucault, M. (1965) Madness and Civilization; A History of Insanity in the Age of Reason, Pantheon Books, New York.

Foucault, M. (1972) The Archaeology of Knowledge, Routledge, London.

Frenkel, M. (2008) 'The multinational corporation as a third space: rethinking international management discourse on knowledge transfer through Homi Bhabha', Academy of Management Review, Vol. 33, No. 4, pp.924-942.

Frenkel, M. and Shenhav, Y. (2006) 'From binarism back to hybridity: a postcolonial reading of management and organization studies', Organization Studies, Vol. 27, No. 6, pp.855-876.

Gandt, R. (1995) Skygods. The Fall of Pan Am, William Morrow and Company, Inc, New York.

Hartt, C.M., Mills, A.J., Mills, J.H. and Durepos, G. (2012) 'Markets, organizations, institutions and national identity: Pan American Airways, postcoloniality and Latin America', Critical Perspectives on International Business, Vol. 8, No. 1, pp.14-36.

Iggers, G. (1997) Historiography in the Twentieth Century: From Scientific Objectivity to the Postmodern Challenge, Wesleyan University Press, Hanover, NH.

Jackson, T. (2012) 'Postcolonialism and organizational knowledge in the wake of China's presence in Africa: interrogating south-south relations’, Organization, Vol. 19, No. 2, pp.181-204.

Jenkins, K. (1991) Re-Thinking History, Routledge, London; New York.

Jenkins, K., Morgan, S. and Munslow, A. (2007) Manifestos for History, Routledge, London; New York.

Josephson, M. (1943) Empire of the Air, Juan Trippe and the Struggle for World Airways, Harcourt Brace and Co, New York. 
Kalela, J. (2012) Making History. The Historian and Uses of the Past, Palgrave/MacMillan, London.

Kipping, M. and Üsdiken, B. (2008) 'Business history and management studies', Jones, G. and Zeitlin, J. (Eds.): The Oxford Handbook of Business History, pp.96-113, Oxford University Press, Oxford.

Krysa, I., T.L. Kien, J. Helms Mills, and A.J. Mills (2016) 'Postcoloniality in action: RAND during the Vietnam War', Critical Perspectives on International Business, in press.

Latour, B. (2005) Reassembling the Social, Oxford University Press, Oxford.

Lemisch, J. (1975) On Active Service in War and Peace: Politics and Ideology in the American Historical Profession, New Hogtown Press, Toronto.

Lockwood, J.E. and Smith, L.E. (1941) 'Intra-governmental activities of the United States to foster hemispheric trade', Law and Contemporary Problems, Vol. 8, No. 4, pp.669-683.

Lyotard, J-F. (1993) The Postmodern Condition: A Report on Knowledge, University of Minnesota Press, Minneapolis.

McKenna, S. (2010) 'Managerial narratives: a dialogical approach to understanding managerial identity', Qualitative Research in Organizations and Management: An International Journal, Vol. 5, No. 1, pp.5-27.

Mignolo, W.D. (1991) The Idea of Latin America, Blackwell, Oxford.

Mills, A.J. (2006) Sex, Strategy and the Stratosphere: Airlines and the Gendering of Organizational Culture, Palgrave Macmillan, London.

Mills, A.J. and Mills, J.H. (2011) 'Digging archeology: postpositivist theory and archival research in case study Development', in Piekkari, R. and Welch, C. (Eds.): Rethinking the Case Study in International Business Research, pp.342-360, Edward Elgar Publishing, Northampton, MA.

Mir, R., Banerjee, S.B. and Mir, A. (2008) 'Hegemony and its discontents: a critical analysis of organizational knowledge transfer', Critical Perspectives on International Business, Vol. 4, Nos. 2-3, pp.203-227.

Munslow, A. (2010) The Future of History, Palgrave MacMillan, London.

Newton, W. (1978) The Perilous Sky: U.S. Aviation Diplomacy and Latin America, 1919-1931, Florida University of Miami Press, Coral Gables.

Pan American Airways (1930a) 'Our real job’, Pan American Air Ways, Vol. 1, No. 5, p.30.

Pan American Airways (1930b) 'Pan American equipment finest in world', Pan American Air Ways, 24 February, Anniversary Number.

Pan American Airways (1930c) ‘Pioneer?’, Pan American Airways, Vol. 1, No. 15, pp.78.

Pan American Airways (1931a) Annual Report, Pan American Airways Corporation, New York.

Pan American Airways (1931b) 'Seventeen countries served by Air Express. Clearance simplified', Pan American Air Ways, Vol. 2, No. 3, pp.129, 132.

Pan American Airways (1932) 'Cuban Air System acquired by Pan American’, Pan American Air Ways, Vol. 3, No. 2.

Pan American Airways (1943) 'Avensa', New Horizons, December, p.13.

Pan American Airways (1950) Address by Juan T. Trippe, President, Pan American World Airways, At Christening of the Clipper Friendship, 4 July, Buenos Aires.

Pan American Airways (1957) Brazil Plays Big Role in PAA's First 30 Years, Press Release, 29 October, Public Relations - Latin American Division.

Pan American Airways Corporation (1930) 'Join all Americas in world's greatest air transport system', Pan American Air Ways, Vol. 1, No. 10.

Pan American Airways Corporation (1934) Annual Report, New York.

Pan American Airways Corporation (1935) Annual Report, New York.

Pan American World Airways (1943) Annual Report, New York. 
Pan American World Airways (1942) Story of the Eastern ('Mother') Division. Pan American Airways System, 1927-1942, Pan Am History, Pan American World Airways Special Collection 341, (Box 14/Folder 13), Otto Richter Library/University of Miami.

Pan American World Airways (1944) 'Truth and Pan American', Pan Americana, Vol. 1, No. 7.

Patel, K.K. (2015) The New Deal: A Global History, America in the World, Princeton University Press, Princeton.

Prasad, A. (Ed.) (2003) Postcolonial Theory and Organizational Analysis: A Critical Engagement, Palgrave, London.

Rowlinson, M., Casey, A., Hansen, P.H. and Mills, A.J. (2014) 'Narratives and memory in organizations', Organization, Vol. 21, No. 4, pp.441-446.

Said, E.W. (1979) Orientalism, Vintage, New York.

Scott, W.R. and Christensen, S. (1995) 'Conclusion: crafting a wider lens', in Scott, W.R. and Christensen, S. (Eds.): The Institutional Construction of Organizations, pp.302-313, Sage, Thousand Oaks, CA.

Turner, P.S.J. (1976) Pictorial History of Pan American Airways, Ian Allan, Shepperton.

Vaara, E. and Tienari, J. (2011) 'On the narrative construction of multinational corporations: an antenarrative analysis of legitimation and resistance in a cross-border merger', Organization Science, Vol. 22, No. 2, pp.370-390.

Westwood, R. and Jack, G. (2008) 'The US commercial-military-political complex and the emergence of international business and management studies', Critical Perspectives on International Business, Vol. 4, No. 4, pp.367-388.

White, H. (1973) Metahistory: The Historical Imagination in Nineteenth-Century Europe, The Johns Hopkins University Press, Balitimore, MD.

White, H. (1984) 'The question of narrative in contemporary historical theory', History and Theory, Vol. 23, No. 1, pp.1-33.

White, H. (1987) The Content of the Form: Narrative Discourse and Historical Representation, John Hopkins University Press, London.

Wilkins, M. (1974) The Maturing of Multinational Enterprise. American Business Abroad from 1914 to 1970, Harvard University Press, Cambridge, MA.

Young, R.J.C. (2001) Postcolonialism: An Historical Introduction, Blackwell Publishers Ltd, Oxford.

Zinn, H. (1999) A People’s History of the United States. 1492-Present, HarperCollins, New York.

\section{Notes}

1 Although the following year they were still referring to the Caribbean and the Mexican Divisions. From 1930, the annual reports were issued in the name of the airline, which was then called Pan American Airways Corporation. In 1941, the airline name was changed to Pan American World Airways.

2 In later years this would be replaced with the notion of globalisation and the narrative of MNE's as vehicles of globalisation; however, while MNE's are often accused of imposing Western culture on the host markets, the Pan Am rhetoric claims to provide mutual learning.

3 We use the term 'archival' in both the restricted sense of a 'housed' collection of corporate documents and the Foucauldian (1972) sense of a field of inter-related documents and artefacts (see Mills and Mills, 2011). This involved analysis not only of archived materials (at the Otto Richter Library) but also newspaper accounts and especially existing written histories that we also treated as narrative accounts.

4 Here we are referring to Foucault's (1972) sense of the archive as 'a field of inter-related documents and artefacts' (see note 3 ). 